Nota de Investigaciän/Research Note

Microgasterópodos asociados con el banco natural de la pepitona Arca zebra (Swainson, 1833; Mollusca: Bivalvia) ubicado en la localidad de Chacopata, Estado Sucre, Venezuela

\title{
Microgastropods associated with the natural bank of Arca zebra (Swainson, 1833; Mollusca: Bivalvia) located in Chacopata, Sucre State, Venezuela
}

\author{
Samuel Narciso ${ }^{1}$ \\ Antulio Prieto-Arcas ${ }^{2}$ \\ Vanessa Acosta-Balbás²* \\ ${ }^{1}$ Fundación para la Defensa de la Naturaleza (FUDENA) \\ Estación de Chichiriviche \\ Estado Falcón, Venezuela \\ E-mail: snarciso@fudena.org.ve \\ ${ }^{2}$ Departamento de Biología, Escuela de Ciencias \\ Universidad de Oriente \\ Apartado 245 \\ Cumaná, Estado Sucre, Venezuela \\ *E-mail: vacosta@sucre.udo.edu.ve \\ Recibido en febrero de 2004; aceptado en agosto de 2004
}

\section{Resumen}

El objetivo de este estudio fue analizar la taxonomía de los microgasterópodos asociados con el bivalvo Arca zebra, un importante recurso pesquero del nororiente de Venezuela. Las muestras se obtuvieron con rastras metálicas en la localidad de Chacopata, Estado Sucre, Venezuela. Se recolectaron un total de 381 gasterópodos pertenecientes a 25 especies incluidas en 12 familias, de las cuales las más diversas, de acuerdo con el número de especies, fueron Marginellidae (4), Collumbelidae (4) y Fisurellidae (3). Del total de las especies recolectadas, siete (Marginella haematita, Lucapina sowerby, Cantharus cancellarius, Crassispira tampanensis, Pyrgocytara coxi, Monilispira leusosyma y Terebra nasulla) representan nuevos registros para Venezuela, aunque pueden catalogarse como típicas del Atlántico tropical occidental.

Palabras clave: micromoluscos, bivalvos, costas de Venezuela.

\begin{abstract}
The objective of this study was to analyze the taxonomy of microgastropods associated with the bivalve Arca zebra, an important fishing resource of the northern coast of Venezuela. The samples were obtained in the area of Chacopata, Sucre State, Venezuela. A total of 381 gasteropods were collected belonging to 25 species included in 12 families. The families with the highest number of species were Margellinidae (4), Collumbelidae (4) and Fisurellidae (3). Of the total of species collected, seven (Marginella haematita, Lucapina sowerby, Cantharus cancellarius, Crassispira tampanensis, Pyrgocytara coxi, Monilispira leusosyma and Terebra nasulla) represent new records for Venezuela, but can be catalogued as typical of the tropical western Atlantic.
\end{abstract}

Key words: micromollusks, bivalves, coast of Venezuela.

\section{Introducción}

Las investigaciones sobre micromoluscos en Venezuela son escasas. El primer trabajo con un enfoque estrictamente ecológico fue el realizado por Martínez (1964) sobre Bittium carabobensis en la Laguna de Unare, Estado Anzoátegui. Posteriormente, Flores (1973a, b) analizó tanto la taxonomía como la zonación de la familia Littorinidae en las aguas costeras de Venezuela. Princz $(1973,1977)$ realizó un estudio donde

\section{Introduction}

Research on micromollusks in Venezuela is scarce. The first study with a strict ecological focus was made on Bittium carabobensis by Martínez (1964) at Unare Lagoon in the state of Anzoátegui. Later, Flores (1973a, b) analyzed the taxonomy and zonification of the family Littorinidae in Venezuelan coastal waters. Princz $(1973,1977)$ obtained information about gastropods and pelecypods in the state of Nueva Esparta and 
aportó información sobre gasterópodos y pelecípodos del Estado Nueva Esparta y sobre micromoluscos en la plataforma de Guayana y, en 1986, describió aspectos ecológicos sobre la distribución de los moluscos bentónicos del nororiente de Venezuela. A partir de 1990 se generó más información sobre los moluscos de la plataforma continental de Margarita, Coche y Chacopata (Carvajal y Capelo, 1992), los moluscos de la Bahía de Pozuelos, Estado Anzoátegui (Buitrago y Capelo, 1993) y los del Golfo de Cariaco (Prieto et al., 1999).

Hasta el momento la información sobre micromoluscos gasterópodos asociados con la pepitona Arca zebra en el banco de Chacopata es deficiente y se encuentra parcialmente recopilada por Capelo y Buitrago (1998) y Prieto et al. (2001).

Los moluscos, particularmente bivalvos y gasterópodos, constituyen el componente más sobresaliente de la fauna bentónica de la región oriental de Venezuela, donde se encuentran especies importantes desde el punto de vista pesquero, como la pepitona A. zebra y la madreperla Pinctada imbricata. Otras especies, como la vaquita Strombus pugilis (Linné, 1758) y miembros de las familias Muricidae y Pectinidae son explotadas por los pescadores para el consumo local.

Arca zebra (Swainson, 1833), un pelecípodo perteneciente al orden Filibranquia, familia Arcidae, es conocido como pepitona o pata de cabra, siendo muy abundante en las aguas someras de la región oriental de Venezuela, donde se localiza formando bancos naturales extensos, los cuales constituyen un recurso pesquero de importancia comercial que tiene alto impacto socioeconómico en la región nororiental, principalmente en algunas comunidades de los estados Sucre y Nueva Esparta. Sobre esta especie se tienen conocimientos acerca de su crecimiento (Prieto y Saint-Aubyn, 1998), producción específica (Saint-Aubyn et al., 1998), aspectos pesqueros (Novoa et al., 1999) y estructura comunitaria; así como de macromoluscos asociados, donde se incluye la fauna acompañante (Prieto et al., 2001); sin embargo, la información disponible sobre los micromoluscos asociados es muy escasa.

Gran cantidad de moluscos marinos son organismos pequeños, con tallas máximas menores a $5 \mathrm{~mm}$, y por diversas razones metodológicas muchas especies de micromoluscos escapan o no son capturadas en los muestreos, por lo que son regularmente menos conocidos taxonómicamente que las especies grandes (macromoluscos). A pesar de ello, los micromoluscos son numéricamente muy abundantes, constituyendo un componente muy importante de la fauna presente en las comunidades intermareal y sublitorales de las costas venezolanas.

Dada la escasa información que existe respecto a los microgasterópodos y como contribución al conocimiento de este grupo, se realizó un inventario de este grupo asociado al banco de la pepitona A. zebra. Además de ello, esta información formará parte de una colección de referencia que servirá de material de consulta para investigaciones futuras. Es importante destacar que las colecciones de referencia son esenciales en los estudios sobre biodiversidad, conservación y manejo de ecosistemas. En este caso específico representa un aporte al about micromollusks on the Guayana shelf. Princz (1986) also described ecological aspects of the benthonic mollusks distribution in northwestern Venezuela. Since 1990, more information has been made available on mollusks from the continental shelf of Margarita, Coche and Chacopata (Carvajal and Capelo, 1992), mollusks from Pozuelos Bay, Anzoátegui (Buitrago and Capelo, 1993) and mollusks from the Gulf of Cariaco (Prieto et al., 1999).

To date, information regarding gastropod micromollusks associated with Arca zebra in the Chacopata bank is deficient and partially collected in the works of Capelo and Buitrago (1998) and Prieto et al. (2001).

The most outstanding components of the benthonic fauna found in eastern Venezuela are especially bivalves and gastropod mollusks. Here, from a fishery point of view, important species such as A. zebra and Pinctada imbricata are found. Fishermen exploit other species such as Strombus pugilis (Linne, 1758) and members of the families Muricidae and Pectinidae for local consumption.

Arca zebra (Swainson, 1833), known as turkeywing or goat's foot, is a pelecypod belonging to the order Filibranquia, family Arcidae. In the eastern region of Venezuela, this species is abundant in shallow waters, forming extensive natural banks. It is an important commercial fishing resource that has a high socio-economic impact in the northeastern region, mainly in some communities in the states of Sucre and Nueva Esparta. Information is available regarding its growth (Prieto and SaintAubyn, 1998), specific production (Saint-Aubyn et al., 1998), fishing aspects (Novoa et al., 1999) and community structure. Information is also available regarding associated macromollusks, including the accompanying fauna (Prieto et al., 2001); however, information on the associated micromollusks is very scarce.

Many marine mollusks are small organisms that measure $5 \mathrm{~mm}$ at most and usually less than this. For several methodological reasons, many micromollusk species escape or are not captured in the samples and are therefore less well known taxonomically than the larger species (macromollusks). Nevertheless, they are numerous and constitute an important part of the fauna present in intertidal and sublittoral communities of the Venezuelan coasts.

In order to contribute to the knowledge of microgastropods, an inventory was made of this group associated with the $A$. zebra bank, which will be part of a reference collection to be used for future research work. It is important to emphasize that reference collections are essential for biodiversity studies, conservation and ecosystem management. This specific inventory represents a contribution to the information about microgastropod biodiversity in the southern Caribbean and in particular the state of Sucre, Venezuela.

\section{Materials and methods}

Samples were taken from the A. zebra bank in Chacopata, between Caribe Island and Morro de Chacopata, state of Sucre 
conocimiento de la biodiversidad de microgasterópodos en el Caribe Sur y en particular en el Estado Sucre.

\section{Materiales y métodos}

En diciembre de 2002, se realizaron ocho arrastres de tres minutos cada uno, empleando una rastra para moluscos de $1 \mathrm{~m}$ $\times 0.80 \mathrm{~m} \times 0.5 \mathrm{~m}$, con una abertura de malla de $8 \mathrm{~mm}$, desde una embarcación pesquera a una profundidad aproximada entre 4 y $8 \mathrm{~m}$, en el banco de $A$. zebra ubicado en la localidad de Chacopata, entre Isla Caribe y el Morro de Chacopata, Estado Sucre, Venezuela $\left(10^{\circ} 42^{\prime} 30^{\prime \prime} \mathrm{N}\right.$ y $63^{\circ} 48^{\prime} 30^{\prime \prime}$ W). Según Miró (1974) y Álvarez (1987), esta zona se caracteriza por presentar un tipo de substrato de arena media con un diámetro de 0.25 $\mathrm{mm}$.

Una vez en el laboratorio, las muestras de todo el material acompañante de la pepitona se hicieron pasar por tamices de $5 \mathrm{~mm}$. Los microgasterópodos fueron fijados in situ, con una solución de formalina al 10\% neutralizada; también fueron coloreados con rodamina B para su mejor observación y cuantificación. La identificación se realizó empleando las indicaciones y claves taxonómicas de Abbott (1974), Abbott y Boss (1989), Linder (1975), Princz (1986), Carvajal y Capelo (1992) y Díaz y Puyana (1994).

Para la mayoría de las especies se señala el tipo de alimentación según la literatura especializada disponible, además del número bajo el cual serán catalogados en el Centro de Investigación y Atención Comunitaria de la Fundación para la Defensa de la Naturaleza (FUDENA), ubicada en la estación de Chichiriviche, Estado Falcón, que cuenta con una colección de referencia de unas 15,000 especies y más de 4,000 registros.

\section{Resultados y discusión}

Durante los muestreos se recolectaron un total de 378 gasterópodos, pertenecientes a 25 especies incluidas en 12 familias (tabla 1). Las familias más representativas, según el número de individuos capturados, fueron Trochidae con 101, Buccinidae con 55 y Marginellidae con 54. De acuerdo con el número de especies obtenidas, las familias más diversas fueron Marginellidae, con cuatro especies (Hyalina albolineata, $\mathrm{H}$. avena, Persicula pulcherina y Marginella haematita); Collumbelidae, con cuatro especies (Anachis pulchella, A. obesa, A. sparsa y A. floridana); y Fisurellidae, con tres especies (Diodora minuta, D. dysonni y Lucapina sowerby).

El análisis taxonómico de los microgasterópodos recolectados indica que, de las 25 especies identificadas, 7 (Marginella haematita, Lucapina sowerby, Cantharus cancellarius, Crassispira tampanensis, Pyrgocytara coxi, Monilispira leusosyma y Terebra nasulla) constituyen nuevos registros para aguas venezolanas, que no habían sido citados en estudios previos de la región (Buitrago et al., 1984; Carvajal y Capelo, 1992; Capelo y Buitrago, 1994, 1998).

Hyalina avena, registrada en este muestreo, había sido citada previamente para la Isla de La Blanquilla (Talavera y
State, Venezuela $\left(10^{\circ} 42^{\prime} 30^{\prime \prime} \mathrm{N}, 63^{\circ} 48^{\prime} 30^{\prime \prime} \mathrm{W}\right)$, in December 2002. According to Miró (1974) and Álvarez (1987), this area is characterized by a substratum of medium sand measuring $0.25 \mathrm{~mm}$ in diameter.

In water approximately 4-8 m deep, eight 3-min-long trawls were made from a fishing boat, using a mollusk dredge of $1 \mathrm{~m} \times 0.80 \mathrm{~m} \times 0.5 \mathrm{~m}$, with an 8-mm mesh size. In the laboratory, the samples of all the material accompanying $A$. zebra from the dredge were passed through 5-mm sieves. The microgastropods were fixed in situ with a solution of neutralized formalin (10\%) and stained with rhodamine B for better observation and quantification. Identification was made using the indications and taxonomic keys of Abbott (1974), Abbott and Boss (1989), Princz (1986), Carvajal and Capelo (1992) and Díaz and Puyana (1994).

The feeding behavior of most of the species was indicated according the available specialized literature. The species were numerically catalogued at the Center for Research and Community Attention of the Nature Defense Foundation (FUDENA), located at Chichiriviche station, in the state of Falcón, which has a reference collection of some 15,000 species and more than 4,000 records.

\section{Results and discussion}

A total of 378 gastropods were collected from the dredges, belonging to 25 species included in 12 families (table 1 ). The best represented families in terms of the number of individuals captured were Trochidae with 101, Buccinidae with 55 and Marginellidae with 54. Based on the number of species obtained, the most diverse families were Marginellidae with four species (Hyalina albolineata, H. avena, Persicula pulcherina and Marginella haematita); Collumbelidae with four species (Anachis pulchella, A. obesa, A. sparsa and A. floridana); and Fisurellidae with three species (Diodora minuta, D. dysonni and Lucapina sowerby).

The taxonomic analysis of the microgastropods collected indicates that of the 25 species identified, 7 constitute new records for eastern Venezuelan waters: Marginella haematita, Lucapina sowerby, Cantharus cancellarius, Crassipira tampanensis, Pyrgocytara candidissima, Monilispira leusosyma and Terebra nasulla. These have not been cited in previous studies of the region (Buitrago et al., 1984; Carvajal and Capelo, 1992; Capelo and Buitrago, 1994, 1998).

Hyalina avena, recorded in this sample, had been cited previously at Blanquilla Island (Talavera and Princz, 1984) and Mochima Bay (Ramos and Robaina, 1994). Anachis sparsa had also been found at Coche and Margarita islands and the Paria Peninsula (Princz, 1986).

Most of the microgastropod species identified in this study can be catalogued as typical of the western tropical Atlantic and, more specifically, of the southeastern area of the Caribbean Sea, where frequent and intense seasonal coastal upwelling occurs (Fukuoka, 1965; Ferraz-Reyes, 1980, 1989). 
Tabla 1. Lista de especies de microgasterópodos recolectadas en el banco natural de la pepitona Arca zebra (Swainson, 1833), ubicado en Chacopata, Estado Sucre (Venezuela). Se muestra la familia, número de individuos por especies, número de catálogo y el tipo de alimentación que presentan. * Nuevas especies registradas.

Table 1. List of microgastropod species collected from the natural bank of Arca zebra (Swainson, 1833) in Chacopata, Sucre State (Venezuela). The family, number of individuals, catalogue number and feeding behavior are given. * New species recorded.

\begin{tabular}{|c|c|c|c|c|}
\hline $\begin{array}{l}\text { Familia } \\
\text { Clase Gastropoda }\end{array}$ & Especie & $\begin{array}{c}\text { No. de } \\
\text { individuos }\end{array}$ & $\begin{array}{l}\text { Código de } \\
\text { catálogo }\end{array}$ & Tipo de alimentación \\
\hline \multirow[t]{3}{*}{ Fisurellidae } & $\begin{array}{l}\text { Diodora minuta } \\
\text { (Lamark, 1822) }\end{array}$ & 2 & CFSN-002252 & Herbívoro ramoneador \\
\hline & $\begin{array}{l}\text { Diodora dysonni } \\
\text { (Reeve, 1850) }\end{array}$ & 3 & CFSN-002254 & Herbívoro ramoneador \\
\hline & $\begin{array}{l}\text { Lucapina sowerby } \\
\text { (Sowerby, 1835)* }\end{array}$ & 16 & CFSN-002259 & Herbívoro ramoneador \\
\hline Trochoidae & $\begin{array}{l}\text { Tegula fascista } \\
\text { (Born, 1778) }\end{array}$ & 101 & CFSN-002255 & Herbívoro ramoneador \\
\hline \multirow[t]{3}{*}{ Rissoidae } & $\begin{array}{l}\text { Rissoina decussata } \\
\text { (Montagu, 1803) }\end{array}$ & 1 & CFSN-002260 & Herbívoro \\
\hline & Rissoina sp. & 2 & CFSN-002253 & Herbívoro \\
\hline & Albania sp. & 4 & CFSN-002256 & Carnívoro depredador \\
\hline Calyptraeidae & $\begin{array}{l}\text { Crepidula plana } \\
\text { (Say, 1822) }\end{array}$ & 1 & CFSN-002261 & Filtrador suspensívoro \\
\hline Triphorideae & Triphora sp. & 12 & (CFSN-002262) & $\begin{array}{l}\text { Carnívoros depredadores de } \\
\text { organismos incrustantes }\end{array}$ \\
\hline \multirow[t]{2}{*}{ Buccinidae } & $\begin{array}{l}\text { Engina turbinella } \\
\text { (Kiener, 1835) }\end{array}$ & 57 & CFSN-002265 & Carnívoro depredador \\
\hline & $\begin{array}{l}\text { Cantharus cancellarius } \\
\text { (Conrad, 1847)* }\end{array}$ & 1 & CFSN-002257 & Carnívoro depredador \\
\hline \multirow[t]{4}{*}{ Collumbelidae } & $\begin{array}{l}\text { Anachis pulchella } \\
\text { (Sowerby, 1845) }\end{array}$ & 11 & CFSN-002264 & Carnívoro depredador \\
\hline & $\begin{array}{l}\text { Anachis floridana } \\
\text { (Barstch y Rehder, 1939) }\end{array}$ & 21 & CFSN-002270 & Carnívoro depredador \\
\hline & $\begin{array}{l}\text { Anachis obesa } \\
\text { (C.B. Adams, 1845) }\end{array}$ & 16 & CFSN-002269 & Carnívoro depredador \\
\hline & $\begin{array}{l}\text { Anachis sparsa } \\
\text { (L.A. Reeve, 1859) }\end{array}$ & 36 & CFSN-002270 & Carnívoro depredador \\
\hline Nassariidae & $\begin{array}{l}\text { Nassarius albus } \\
\text { (Say, 1826) }\end{array}$ & 2 & CFSN-002268 & Carnívoro depredador \\
\hline \multirow[t]{4}{*}{ Marginellidae } & $\begin{array}{l}\text { Hyalina albolineata } \\
\text { (Orbigny, 1842)* }\end{array}$ & 16 & CFSN-002271 & $\begin{array}{l}\text { Carnívoro depredador de } \\
\text { organismos incrustantes }\end{array}$ \\
\hline & $\begin{array}{l}\text { Hyalina avena } \\
\text { (Kiener, 1834) }\end{array}$ & 54 & CFSN-002267 & $\begin{array}{l}\text { Carnívoro depredador de } \\
\text { organismos incrustantes }\end{array}$ \\
\hline & $\begin{array}{l}\text { Persicula pulcherina } \\
\text { (Gaskoin, 1849) }\end{array}$ & 9 & CFSN-002272 & $\begin{array}{l}\text { Carnívoro depredador de } \\
\text { organismos incrustantes }\end{array}$ \\
\hline & $\begin{array}{l}\text { Marginella haematita } \\
\text { (Kiener, 1841)* }\end{array}$ & 4 & CFSN-002273 & Detritívoro \\
\hline Turbinidae & $\begin{array}{l}\text { Turbo castanea } \\
\text { (Gemelin, 1791) }\end{array}$ & 3 & CFSN-002278 & Detritívoro \\
\hline
\end{tabular}


(Cont.)

\begin{tabular}{llccl}
\hline $\begin{array}{l}\text { Familia } \\
\text { Clase Gastropoda }\end{array}$ & Especie & $\begin{array}{c}\text { No. de } \\
\text { individuos }\end{array}$ & $\begin{array}{c}\text { Código de } \\
\text { catálogo }\end{array}$ & Tipo de alimentación \\
\hline Turridae & $\begin{array}{l}\text { Crassispira tampanensis } \\
\text { (Barstch y Rehder, 1939)* } \\
\text { Pyrgocytara coxi } \\
\text { (Fargo, 1953)* }\end{array}$ & 1 & CFSN-002266 & Carnívoro depredador \\
$\begin{array}{l}\text { Monilispira leusosyma } \\
\text { (Maury, 1922)* } \\
\text { Terebra nasulla } \\
\text { (Dall, 1889)* } \\
\text { Balcis sp. }\end{array}$ & 5 & CFSN-002275 & Detritívoro \\
& & 1 & CFSN-002276 & $\begin{array}{l}\text { Detritívoro, microalguívoro } \\
\text { y herbívoro } \\
\text { Carnívoros depredadores de } \\
\text { organismos incrustantes }\end{array}$ \\
\hline
\end{tabular}

Princz, 1984) y la Bahía de Mochima (Ramos y Robaina, 1994); igualmente, Anachis sparsa había sido citada para las islas de Coche y Margarita y la Península de Paria (Princz, 1986).

La gran mayoría de las especies identificadas en este estudio pueden catalogarse como típicas del Atlántico tropical occidental y más específicamente de la región suroriental del Mar Caribe, que presenta como característica ambiental la frecuencia e intensidad de surgencias costeras estacionales (Fukuoka, 1965; Ferraz-Reyes, 1980, 1989) que determinan la presencia de especies de bivalvos filtradores capaces de formar bancos naturales de gran abundancia, productividad e importancia. Tal es el caso de Arca zebra en el oriente de Venezuela, lo que explicaría en cierta forma la amplia proporción de microgasterópodos depredadores en la zona, ya que éstos representaron el $60 \%$ con relación al $40 \%$ de herbívoros y suspensivoros (tabla 1).

También se identificaron algunas especies de amplia distribución en el nororiente, características de fondos blandos y aguas de salinidad variante, las cuales se encuentran en la Provincia Guayanesa, de transición a la Brasileña, como son Triphora sp., Anachis obesa, A. sparsa, Engina turbinella y Nassarius albus.

\section{Agradecimientos}

La presente investigación fue parcialmente financiada por el Consejo de Investigación de la Universidad de Oriente (proyecto No. CI/5-1001-1094/02).

\section{Referencias}

Abbott, R. (1974). American Seashells. 2nd ed. Van Nostrand Reinhold Co., New York, 663 pp.

Abbott, R. and Boss, K. (1989). A Classification of the Living Mollusca. American Malacogists, Melbourne, Florida, 189 pp.
This upwelling determines the presence of filtering bivalve species capable of forming natural banks of great abundance, productivity and importance, such as Arca zebra in eastern Venezuela. This would explain, to a certain extent, the wide proportion of predatory microgastropods in the zone: $60 \%$ relative to $40 \%$ of herbivores and suspension feeders (table 1 ).

Some species characteristic of soft bottoms and variable saline waters that are widely distributed in the northeast were also identified. These species are Triphora sp, Anachis obesa, A. sparsa, Engina turbinella and Nassarius albus.

\section{Acknowledgements}

This study was partially funded by the Research Council of Universidad de Oriente (project No. CI/5-1001-1094/02).

English translation by the authors.

Álvarez, R. (1987). Dinámica sedimentaria en los canales marinos entre la Isla de Margarita, Coche y la Península de Araya (Venezuela). Mem. Soc. Cienc. Nat. La Salle, (127-128): 77-103.

Buitrago, J. y Capelo, J. (1993). Los moluscos bentónicos de la región suroriental de la Bahía de Pozuelos, Puerto La Cruz, Venezuela. Mem. Soc. Cienc. Nat. La Salle, 140: 27-39.

Buitrago, J., Carvajal, F. y Cárdenas, J. (1984). Las comunidades bentónicas de los canales Margarita-Coche-Araya. Acta Cient. Venezolana, 35 (Supp.1): 367.

Capelo, J. y Buitrago, J. (1994). Presencia de Typhis (Rugotyphis) cleryi Petit de la Saussage, 1840, en las aguas costeras de Venezuela. Mem. Soc. Cienc. Nat. La Salle, 141: 27-39.

Capelo, J. y Buitrago, J. (1998). Distribución geográfica de los moluscos marinos en el oriente de Venezuela. Mem. Soc. Cienc. Nat. La Salle, 273: 109-160.

Carvajal, F. y Capelo, J. (1992). Moluscos de la Plataforma MargaritaCoche-Tierra Firme (Venezuela). Su distribución y abundancia. Mem. Soc. Cienc. Nat. La Salle, 140: 159-175.

Díaz, J. y Puyana, M. (1994). Moluscos del Caribe Colombiano. Colciencias, Fundación Natura, Invemar, Bogotá, 323 pp. 
Ferraz-Reyes, E. (1980). Productividad primaria del Golfo de Cariaco, Venezuela. Bol. Inst. Oceanogr. Univ. Oriente, 26: 97-110.

Ferraz-Reyes, E. (1989). Influencia de los factores físicos en la distribución vertical de la biomasa fitoplanctónica en el Golfo de Cariaco (Venezuela). Bol. Inst. Oceanogr. Univ. Oriente, 28: 47-56.

Flores, C. (1973a). La Familia Littorinidae (Mollusca: Mesogastropoda) en las aguas del nororiente de Venezuela. Bol. Inst. Oceanogr. Univ. Oriente, 12(1): 3-22.

Flores, C. (1973b). Notas sobre la distribución horizontal y vertical de la familia Littorinidae (Mollusca: Mesogastropoda) en las aguas costeras de Venezuela. Bol. Inst. Oceanogr. Univ. Oriente, 12(1): 67-74.

Fukuoka, J. (1965). Hydrography of the adjacent sea (II). Some characteristics of oceanographical conditions in the Caribbean Sea, especially in the region adjacent to Venezuela. Bol. Inst. Oceanogr. Univ. Oriente, 4(2): 234-245.

Lindner, G. (1975). Field Guide to Sea Shell of the World. Van Nostrand Reinhold Co., New York, 170 pp.

Martínez, R. (1964). Ecología de Bittum caraboboense (Wersbord, 1962), gasterópodo prosobranquio béntico de la Laguna de Unare. En: Contribución al Estudio de la Laguna de Unare. Tomo I. Informe de Obras Hidráulicas del MOP. Bol. Inst. Oceanogr. Univ. Oriente, pp. 126-147.

Miró, O. (1974). Morfología submarina y sedimentos marinos recientes del margen continental del nororiente de Venezuela (publicaciones de la Comisión Organizadora de la II Conferencia de las Naciones Unidas sobre Derecho del Mar). Cuadernos Azules, ONU, 14: 1-30.

Novoa, D., Mendoza, J., Marcano, L. y Cárdenas, J. (1999). Atlas Pesquero Marítimo de Venezuela. MAC-SARPA y VECEP, Caracas, 197 pp.
Prieto, A. y Saint-Aubyn, M. (1998). Crecimiento del bivalvo Arca zebra (Swainson, 1883) en Chacopata, Estado Sucre, Venezuela. Saber, 10: 14-19.

Prieto, A., Graterol, A., Campos, I. y Arrieche, D. (1999). Diversidad de moluscos en dos localidades del Golfo de Cariaco, Estado Sucre, Venezuela. Mem. Soc. Cienc. Nat. La Salle, 151: 117-132.

Prieto, A., Ruiz, L., García, N. y Álvarez, M. (2001). Diversidad malacológica en una comunidad de Arca zebra (Mollusca: Bivalvia) en Chacopata, Estado Sucre, Venezuela. Rev. Biol. Trop., 49 (2): 591-598.

Princz, D. (1973). Los moluscos gasterópodos y pelecípodos del Estado Nueva Esparta, Venezuela. Mem. Soc. Cienc. Nat. La Salle, 33: 169-222.

Princz, D. (1977). Notas sobre algunos micromoluscos de la plataforma de Guayana. Mem. Soc. Cienc. Nat. La Salle, 36(108): 283-293.

Princz, D. (1986). Bionomie des micromollusques benthiques du nord-est du Venezuela. Tesis de doctorado, Université de Bretagne Occidentale, Brest, 176 pp.

Ramos, H. y Robaina, G. (1994). Contribución al conocimiento de los moluscos gasterópodos y pelecípodos de la Bahía de Mochima, Estado Sucre, Venezuela. Mem. Soc. Cienc. Nat. La Salle, 54(141): 95-106.

Saint-Aubyn, M., Prieto, A. y Ruiz, L. (1998). Producción específica de una población del bivalvo Arca zebra (Swainson, 1983) en la costa nororiental del Estado Sucre, Venezuela. Acta Cient. Venezolana, 50: 15-23.

Talavera, F. y Princz, D. (1984). Marginella iasallei y algunos datos sobre la familia Marginellidae (Mollusca: Neogastropoda) en el mar venezolano. Bol. Malc., 20(9-12): 273-282. 